\title{
Mood and Transitivity in South Efate
}

\author{
Nick Thieberger
}

\author{
UNIVERSITY OF MELBOURNE
}

\begin{abstract}
South Efate, an Oceanic language of central Vanuatu, allows the expression of temporal relations in several ways using markers of aspect and mood. Pronominal expression of arguments is obligatory and, as subject proclitics occur in one of three forms (realis, irrealis. and perfect), expression of aspect or mood is required in every sentence. South Efate is one of a group of Vanuatu languages that displays stem-initial mutation, whereby the initial consonant of a very small group of verbs changes to reflect mood. This paper presents evidence that fortis (realis) and lenis (irrealis) stem mutation also correlates with features of transitivity, not a surprising finding following the work of Hopper and Thompson. All else being equal, the fortis form of the verb occurs in clauses that have an overt expression of an object, while the lenis form occurs when there is no object in the clause. A further curiosity is that stem-initial mutation has been maintained for just a small class of verbs, so its correlation with transitivity in just this small class is all the more interesting. This paper explores the relationship between the morphological expression of mood and transitivity in South Efate, and suggests frequency of use as an explanation for the retention of this marginal system that affects only 7 percent of verb stems in the lexicon.
\end{abstract}

1. INTRODUCTION. ${ }^{1}$ South Efate is an agglutinating head-marking language of the Oceanic branch of Eastern Malayo-Polynesian. Speakers of South Efate live in villages around the south coast of Efate (Central Vanuatu) and currently number somewhere around five to six thousand. Despite the proximity of the capital city, Port Vila, the language is relatively strong and is still being learned by children.

1. Thanks to Manuel Wayane, Endis Kalsarap, and Joel Kalpram for their help in teaching me about South Efate. This paper has greatly benefited from discussions with Alexandre François and from comments by an anonymous reviewer. The main data on South Efate consist of about 30 hours of recordings of a variety of speakers, mainly telling stories, but also include several multiparticipant discussions and two public court hearings, all recorded between 1998 and 2010. Fieldwork was funded by the School of Languages and Linguistics, University of Melbourne. The work reported here was partly funded by Australian Research Council grants DP0450342 and DP0984419. Note that $/ \tilde{\mathrm{m}} /$ and $/ \tilde{\mathrm{p}} /$ represent the labiovelar nasal and stop, respectively, while /g/ is the velar nasal. Abbreviations follow the Leipzig Glossing Rules with the exception of the following: ASP, aspect; CPL, 'completely', used for the postverbal su; DP, direct possession; DST, "distant” enclitic; ESBJ, echo subject; IR, irrealis; PREP, preposition; PSP, prospective; R, realis; TR, transitive suffix; TS, transitivizing suffix; VC, verbal complex. Sources of examples are given either as text numbers with sentence identifiers or as archived audio filenames with start and end times. 
In Thieberger (2007), I suggested that serial verb constructions in South Efate are quite different in scope and kind from the type of serial verb constructions described for languages to the north. In this paper, I show that another feature of South Efate, stem-initial mutation (SIM), is also quite different in its range and function from SIM described for more northern languages. In South Efate, SIM involves the alternation of the first consonant of a small set of verbs between fortis / $\mathrm{p} /$ and lenis / $\mathrm{f} /$, largely correlated with mood, as will be discussed further below. The verbs involved in this process are set out in table 1 , which also shows their frequency of occurrence in the current dataset.

In example (1), the verb $p a$ 'go' appears with a lenited initial consonant as $f a$ 'go irrealis' following the irrealis subject ( $\tilde{p} a$ ' 2 SG.IR'), while the realis form is used following the realis pronoun ( $k u=$ '2SG.R') in (2).
(1) $\tilde{\mathrm{Pa}}=\mathbf{f a}=\mathrm{n} \quad$ pregptak-ki pano. 2SG.IR=go.IR=DST make.ready-TR panel
'You go and prepare the panel.'

(98018az, 2254.9, 2257.9)

(2) $\mathrm{Me}$ ag $\mathrm{ku}=\mathbf{p a}=\mathrm{n} \quad$ lek maarik Sailas?

and 2SG 2SG.R=go.R=DST look mister Sailas

'And did you go to see Mister Sailas?' (NT1-004-A 1606.58, 1615.12)

It will be shown that there is an additional function served by SIM in reflecting the transitivity of the clause which, as suggested in the typological survey of many languages by Hopper and Thompson (1980), aligns irrealis mood with lower transitivity in South Efate.

2. MOOD AND ASPECT MARKING. The categories of realis and irrealis mood are central to most utterances in South Efate. In common with many Oceanic lan-

\section{TABLE 1. FREQUENCY OF ALL SIM-ELIGIBLE WORD TOKENS IN THE DATASET (PAIRED FORTIS AND LENIS WHERE POSSIBLE) ${ }^{\dagger}$}

\begin{tabular}{|c|c|c|c|}
\hline VERB & FREQUENCY & VERB & FREQUENCY \\
\hline pan 'go.R' / fan'go.IR' & $263 / 29$ & puet 'pull.R' / fuet 'pull.IR' & $11 / 1$ \\
\hline pi 'be.R' / fi 'be.IR' & $226 / 3$ & puetsok 'catch.R' / fuetsok & $11 / 1$ \\
\hline pak 'go to.R' / fak 'go to.IR' & $223 / 18$ & 'catch.IR' & \\
\hline fo 'PSP.IR' / po 'PSP.R' & $153 / 15$ & palus 'paddle.R' / falus & $10 / 3$ \\
\hline preg 'make.R' / freg 'make.IR' & $204 / 151$ & 'paddle.IR' & \\
\hline pa 'go.R' / fa 'go.IR' & $133 / 5$ & pestaf 'talk to.R' / festaf 'talk to.IR' & $9 / 1$ \\
\hline piatlak 'have.R' / fiatlak 'have.IR' & $123 /$ & pakelag 'ascend.R' / fakelag & $3 / 1$ \\
\hline pato 'be at.R'/ fato 'be at.IR' & $51 /$ & 'ascend.IR' & \\
\hline paakor 'appear.R' & 32 & fsaplil 'argue.IR' & 2 \\
\hline pam 'eat.R' / fam 'eat.IR' & $31 / 30$ & paaktof 'pay for.R' & 2 \\
\hline pei 'be.first.R' / fei 'be.first.IR' & $27 / 19$ & paareki 'because of.R' & 2 \\
\hline pañor 'find.R' & 19 & paketan 'go down.R' / faketan 'go & $2 / 1$ \\
\hline paos 'ask.R'/ faos 'ask.IR' & $19 /$ & down.IR' & \\
\hline pes 'talk.R' / fes 'talk.IR' & $15 /$ & pau 'weave.R' & 2 \\
\hline pram 'be tall.R' & 11 & paalag 'stand on something.R' & 1 \\
\hline puet 'pull.R' / fuet 'pull.IR' & $11 /$ & psaplil 'argue.R' / fsaplil 'argue.IR' & $1 / 2$ \\
\hline pram 'be tall.R & 11 & fuk 'swell.IR' & 1 \\
\hline
\end{tabular}

Not all eligible forms occur in the corpus. 
guages (Lynch, Ross, and Crowley 2002:35), pronominal subject proclitics have separate paradigms for realis and irrealis. However, unlike the more general pattern, South Efate also has a pronominal paradigm for what I am calling perfect aspect (see the discussion below), all listed in table 2 . As the subject proclitic is an obligatory element in any sentence, speakers are always required to make the distinction between these three categories.

The verb complex in South Efate has the following structure, with a subject and verb being the only obligatory items (for an intransitive verb). The rationale for positing a class of auxiliary verbs is discussed in Thieberger $(2006 \mathrm{~b}, 2007)$.

$$
\text { (3) } \mathrm{S}=\left(\text { PVC) (Benefactive Phrase) } \mathrm{V}\left\{\begin{array}{l}
=\mathrm{O} \text { Pron } \\
\mathrm{ONP}
\end{array}\right\}\right.
$$

The preverbal complex (PVC) is made up of a number of elements as outlined below.

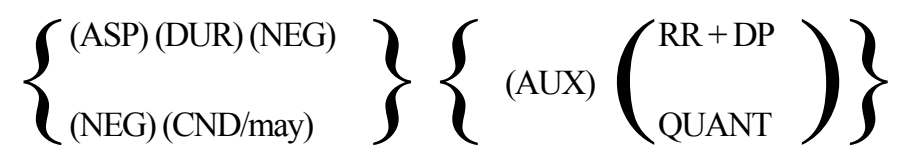

ASP: Aspect

DUR: Durative

NEG: Negation, in two parts, the first $(t a)$ preceding the negated proposition, and the second ( $\mathrm{mau}$ ' $\mathrm{NEG} 2$ ') following it. The first part of the negation may also occur within the AUX, depending on the scope of the negation.

$\mathrm{CND}$ /may: Conditional / may AUX: Auxiliary verb

RR + DP: Reflexive/reciprocal and direct possessive suffix

QUANT: Quantifier

Some examples of the preverbal complex follow, each showing (in the third line) how the elements relate to the schema above.

TABLE 2. PROCLITIC SUBJECT PRONOMINALS

$\begin{array}{llll} & \text { REALIS } & \text { IRREALIS } & \text { PERFECT } \\ \text { 1SG } & \mathrm{a}= & \mathrm{ka}= & \mathrm{kai}= \\ \text { 2SG } & \mathrm{ku}= & \tilde{\mathrm{p}}= & \mathrm{kui}= \\ \text { 3SG } & \mathrm{i}= & \mathrm{ke}= & \mathrm{ki}= \\ \text { 1INCL.DU } & \mathrm{ta}= & \mathrm{tak}= & \text { takai }= \\ \text { 1EXCL.DU } & \mathrm{ra}= & \mathrm{rak}= & \mathrm{rakai}= \\ \text { 2DU } & \mathrm{ra}= & \mathrm{rak}= & \mathrm{rakai}= \\ \text { 3DU } & \mathrm{ra}= & \mathrm{rak}= & \mathrm{rakai}=/ \mathrm{rai}= \\ \text { 1INCL.PL } & \mathrm{tu}= & \mathrm{tuk}= & \mathrm{tu}=, \text { tui }=/ \text { (tukoi=) } \\ \text { 1EXCL.PL } & \mathrm{u}= & \mathrm{ko}= & \mathrm{ui}=/ \mathrm{koi}= \\ \text { 2PL } & \mathrm{u}= & \mathrm{ko}= & \mathrm{koi}= \\ \text { 3PL } & \mathrm{ru}= & \mathrm{ruk}= & \mathrm{rui}=/ \text { (rukui=) }\end{array}$


(5) Ale kai=pe mai to esum̃.

ok 1SG.PRF=PF come stay house

$\mathrm{S}=$ ASP AUX VERB

'Okay, I came and stayed at home.' (NT1-98010-B, 1057.974, 1061.174)

(6) Tiawi ru=ta to mtir natus mau tetwei.

old.people 3PL.R=NEG PROG write book NEG2 long.ago

$\mathrm{S}=\mathrm{NEG}$ AUX VERB

'The old people didn't write books in those days.'

(NT1-20003-A, 497.2, 500.4)

The two aspects morphologically encoded in South Efate are perfect and prospective (see Thieberger 2006a:149 ff.). The perfect in South Efate, following Comrie (1976:52), refers to a past situation that is completed relative to the time established within the utterance, or the "temporal frame." Prospective aspect encodes events that occur after, or are prospective from, the time established within the "temporal frame."

Particles in the preverbal complex distinguish perfect - pe in example (3) - and prospective aspect, together with alternating initial consonants for realis and irrealis forms of the prospective marker $(p o / f o)$, but not for the perfect marker, for which there is no irrealis form. These particles are listed in table 3. Sentences with no such morphological temporal markers usually have a nonfuture reading and realis pronominal forms.

3. TEMPORAL RELATIONS. As is common among Oceanic languages, there is no grammatical marking of tense, even when the temporal frame of a sentence is in the past or the future, as indicated by lexically encoded temporal notions. The marking of mood is obligatory: thus in example (7), while the timeframe is nanom 'yesterday', there is no morphological encoding of past time in the sentence, and the realis form of the proclitic is used.

(7) Nanom pog, $u=$ mai praktis. yesterday night 1EXCL.PL.R=come practice

'Yesterday evening we came to practice.' (NT1-98010-B, 705.4, 717.1)

Similarly, in (8), there is no tense or aspect marking associated with the verb tae 'to know', even though the temporal frame is nanom 'yesterday'. In the second clause of this example, the prospective aspect is marked by an irrealis form of the subject proclitic, $k e=$

\section{TABLE 3. PARTICLES ENCODING MOOD OR ASPECT INFORMATION IN THE PREVERBAL COMPLEX}

pe $\quad$ Perfect (PRF), required following a perfect pronoun. Does not undergo SIM.

po Prospective, realis (PSP.R) encodes an event that has happened at the time of the utterance (and hence is realis), but is subsequent to the reference time, which may be in the past, present, or future.

fo Prospective, irrealis (PSP.IR) encodes an event that has not yet happened at the time of the utterance (and hence is irrealis), and is subsequent to the reference time, which may be in the past, present, or future.

to Progressive (PROG).

ta Durative (DUR).

2. The perfect as detailed in Comrie (1976:52ff) includes various other criteria that are not dealt with further here. 
'3SG.IR', and the irrealis form of the prospective marker $f o$, marking an event as occurring in the future relative to the reference time.

(8) P̃al-uk i=tae nanom na nai $\mathrm{ke}=\mathrm{fo}$ mlanr mees. brother-1SG.DP 3SG.R =know yesterday COMP water 3SG.IR=PSP.IR cold today 'My brother knew yesterday that the water would be cold today.'

(elicited, Dahl questionnaire \#118)

Again, in (9), the timeframe is established by tetwei 'long ago', but there is no morphological encoding of past time in the sentence.

(9) Go tetwei gar ru=ta pakot-ki mani, go ru=ta pakot-ki tete and long.ago 3PL 3PL.R=NEG pay.R-TR money and 3PL.R=NEG pay.R-TR some namrun pet mau. Gar mit mas kin ru=to ptu-ki- $\emptyset$. thing different NEG2 3PL mat only REL 3PL.R=PROG give.R-TR-3SG.O 'And, long ago, they didn't pay with money or with anything else. They only gave mats.'

(NT1-98002-B, 449.53, 458.2)

Long past events, such as the coming of Christianity, in example (10) (framed by nmalko tetwei 'in the time of darkness long ago'), take a realis proclitic ( $i=$ ' '3SG.R'), but there is no grammatical marker of time.

(10) Nmalko tetwei, i=pitlak nafkal kenen. darkness long.ago $3 \mathrm{SG} . \mathrm{R}=$ have.R fight of.it

'Long ago in the time of darkness, there was a fight for it (for Christianity).'

(NT1-98011-A, 909.45, 914.34)

Since realis often corresponds with past time reference and irrealis corresponds with nonpast, it is tempting to consider them as marking tense. However, consider (11), in which the realis form of the pronoun occurs with $p e$ ' $\mathrm{PF}$ ' in a temporal frame that is in the future ( $m a t o o l$ 'tomorrow'), and the verb pam 'to eat' also has a realis (fortis) form. If the perfect form of the pronoun marked past tense only, it could not be used in this context.

(11) Matool kotfan me ki=pe pam kapu ga. tomorrow afternoon and 3SG.PF.PF eat.R laplap 3SG

'Tomorrow afternoon he will have eaten his laplap.'

(elicited)

In the following example, the timeframe is nanom 'yesterday', and the irrealis marks the pronoun and the prospective ( $f o$ 'PSP.IR'), showing that the irrealis can be used in the past when the activity it encodes is occurring subsequent to the reference time.

(12) Kia nanom na, i=tl-i- $\varnothing \quad$ na $\quad k e=$ fo mai here yesterday HESIT 3SG.R=tell-TS-3SG.O COMP 3SG.IR=PSP.IR come kotfan mees. afternoon today 'Yesterday he said he would come this afternoon.'

(NT1-98004-A, 72.04, 75.29)

The perfect pronoun can be used with future time reference, as seen in (13): here the future event of writing a letter will already be achieved by the time the interlocutor arrives, so the perfect form of the pronoun ( $k a i=$ ' 1 SG.PS') is used. 
(13) Malnen $\tilde{\text { pa }}=$ ler mai me kai=pe mtir leta su. as 2SG.IR=again come and 1SG.PF=PF write letter $\mathrm{CPL}$

'When you return I will have finished writing this letter.'

(Dahl questionnaire example 107)

As we would expect, irrealis is used to encode an event that occurs after a reference temporal frame, even if that frame is in the past, and the event encoded by the irrealis is also now in the past; thus in (14) the travel in the week after the temporal frame is referred to by use of the irrealis form of the pronoun (tuk= '1INCL.PL.IR')

(14) Pan pan pan ru=na wik nentu tuk=fak Solomon. go go go 3PL.R=say week next 1INCL.PL.IR=go.to.IR Solomons 'Until they came and said that the next week we would go to the Solomons.' (NT1-98003-A, 1818.21, 1826.64)

From these examples, we can see that the use of temporal adverbials, mood marking in proclitics, together with aspect marking in the preverbal complex, play an important role in determining temporal relations in the absence of tense marking in South Efate.

4. STEM-INITIAL MUTATION IN VANUATU. Stem-initial mutation (SIM) in various forms has been described for a number of Vanuatu languages, including Paamese (Crowley 1982), the languages of Epi (Tryon 1986), Nguna (Schütz 1968), Ura (Crowley 1999), and Sye (Crowley 1998). SIM involves the initial consonant of a verb having two forms, called oral and nasal grade (Lynch 1975), primary and secondary (Crowley 1982, 1991), or base and secondary (Schütz 1969a), among others. While the mechanism is similar in the group of languages, the function performed by SIM varies from language to language, as outlined in table 4.

\section{TABLE 4. SIMPLIFIED VIEW OF CONSONANTS INVOLVED IN SIM IN CENTRAL VANUATU LANGUAGES}

LANGUAGE

Raga (Walsh 1982:236-37)
Nāti (Crowley 1991:198)
Southeast Ambrym (quoted
in Crowley 1991:185)

Paamese

(Crowley1991:190) ${ }^{\dagger}$

Bierebo (Tryon 1986)

Ngunese (Schütz 1968:21)

South Efate (Thieberger 2006a)

Sye (Crowley 1998)
CONSONANTS ALTERNATED BY SIM

$\mathrm{v} / \mathrm{b}, \mathrm{v}^{\mathrm{w}} / \mathrm{b}^{\mathrm{w}}, \mathrm{t} / \mathrm{d}, \mathrm{g} / \mathrm{y}$

$\mathrm{v} / \mathrm{mp}, \mathrm{t} / \mathrm{nt}, \mathrm{r} / \mathrm{ntr}, \mathrm{w} / \mathrm{mpw}$, ?/nk, k/ $\mathrm{nk}$

$\mathrm{d}, \mathrm{x} / \mathrm{g}, \emptyset / \mathrm{x} / \mathrm{m} / \mathrm{v} / \mathrm{g}$, $\mathrm{h} / \mathrm{m} / \mathrm{v} / \mathrm{g}, \mathrm{h} / \mathrm{x} / \mathrm{m} / \mathrm{v} / \mathrm{g}$, $\mathrm{h} / \mathrm{m} / \mathrm{v} / \mathrm{b}, \mathrm{v} / \mathrm{b}$

Four root forms in six classes based around permutations of $\mathrm{t} / \mathrm{r} / \mathrm{d}, \mathrm{h} / \mathrm{v}, \mathrm{k} / \mathrm{g}$,

$\mathrm{p} / \mathrm{p}^{\mathrm{w}}, \mathrm{nd} / \mathrm{nj}$

$\mathrm{v} / \mathrm{p}, \mathrm{w}, \mathrm{p}^{\mathrm{w}}, \mathrm{k} / \mathrm{\eta}, \mathrm{r} / \mathrm{t}$

$\mathrm{p} / \mathrm{f}$

[complex pattern]
FUNCTIONS OF SIM

Secondary form occurs in irrealis-like settings.

Realis/irrealis.

Complex set of four secondary forms, with the primary stem-initial form in irrealis and at least some of the secondary forms as realis.

Four root forms: in compound nouns; irrealis; in compound verbs/serial verbs; realis.

Realis/irrealis.

Second form is 'realis', first is 'irrealis' [my interpretation of Schütz].

Tealis/irrealis.

Not associated with realis/irrealis.

$\dagger \quad$ Crowley shows there are eleven classes of verb root mutations involving various permutations of these consonants and additional segments. 
Lynch (1975) suggests that oral/nasal alternation in Central Vanuatu languages results from the fusion of preverbal *ma 'realis' and *na 'irrealis'. The areal nature of verb steminitial mutation was one piece of evidence that led Pawley (1972) to suggest central New Hebridean as a subgroup. Crowley (1991) concluded that the shared feature was a result of parallel innovation rather than shared inheritance. As can be seen in table 4, South Efate has only two consonants involved in SIM, a considerably smaller set than is found in languages to the north.

Lynch (1975:96) noted that, in at least some of the languages in which SIM occurs, not all verbs beginning with eligible consonants actually undergo SIM, and that this may indicate either a change in progress or borrowing of terms that then do not undergo the change. Crowley addresses the same issue in Paamese (1991:215), and suggests there is some evidence that stative verbs form one class, perhaps indicating that this class of verbs did not occur with the realis marker *m(i)-.

5. STEM-INITIAL MUTATION IN SOUTH EFATE. ${ }^{3}$ For a small set of only 60 verbs and a few particles in South Efate, a strategy for encoding mood is that the initial consonant alternates between fortis $/ \mathrm{p} /$, in realis contexts, and lenited $/ \mathrm{f} /$, in irrealis contexts. By comparison with the languages to the north discussed earlier, this is a very small set of verbs. In Nāti (Malakula), Crowley (1991:199) notes that it is active verbs that undergo initial mutation, while stative verbs have invariant roots. However, in South Efate there is no apparent semantic or functional class that SIM eligible verbs fall into. Of 870 verbs in the current lexicon, there are only 60 that allow SIM, and a further 203 that have invariant $p / f$ initial phonemes. ${ }^{4}$

SIM occurs following an irrealis pronominal proclitic; so in example (15), the verb $p a$ 'go' appears as $f a$ 'go:IR', while the realis form is used following the realis pronoun $k u=$ '2SG.RD' in (16).

(15) $\tilde{\mathrm{P}} \mathbf{a}=\mathbf{f a}=\mathrm{n}$ pregptak-ki pano. 2SG.IR $=$ go.K make.ready-TR panel 'You go and prepare the panel.'

(98018az, 2254.9, 2257.9)

(16) $\mathrm{Me}$ ag $\mathrm{ku}=\mathbf{p a}=\mathrm{n}$ lek maarik Sailas?

and 2SG 2SG.R=go=DST look mister Sailas

‘And did you go to see Mister Sailas?' (NT1-004-A 1606.58, 1615.12)

As seen in the examples above, the lenited form of the verb stem occurs when it immediately follows the irrealis form of the subject pronoun. ${ }^{5}$ Thus in example (17), the nonlenited form preg 'to make.R' occurs following the auxiliary verb mer 'again', despite the preceding irrealis pronoun $r u k=$ '3PL.IR', which would otherwise be the envi-

3. A superficially similar process of alternation, unrelated to SIM as described here, occurs in some reduplicated forms, as in pes 'to speak' / fesfes 'to cheep' (of a bird), or pul 'to sling' / fulful 'to twirl, spin' (as a rope), and also in nominalised forms like paptais 'to baptise' / nfaptaiswen 'baptism', paos 'to ask' / nfaoswen 'question'.

4. Most but not all $p$-initial verbs in the lexicon have been checked for their ability to undergo SIM. Figures given here should be taken as indicative only.

5. In Thieberger (2006a:252), I accounted for the lack of SIM in verbs following auxiliary verbs as a process of blocking of the irrealis marking by intervening particles. That analysis has been superseded by the present one thanks to discussions with Alex François. 
ronment in which the irrealis form of the verb would occur. In (18), the same pronoun and verb occur together, with no intervening auxiliary verb, and the verb is in the expected irrealis form, showing that when the lenited form marks irrealis it only does so immediately following an irrealis subject pronoun.

(17) $\mathrm{Ke}=$ fo preg boy ruk=mer preg natu-er $\mathrm{ke}=$ skei. 3SG.IR=PSP.IR make boy 3PL.IR=again make foot-3PL.DP 3SG:IR=one Wan fut ale pos. one foot okay post

'He would make the boys put their foot down. One foot, then the post.'

(18) Me tekaaru ru=mur-i-n na ruk=freg sa-ki asel-er. and other 3PL.R=want-TS-3SG.O COMP 3PL.IR=make.IR bad-TR friend-3PL.DP 'But the other one, they wanted to harm their friends.'

Some particles in the preverbal complex are also eligible for mutation and, as would be expected, if they immediately follow the irrealis subject pronoun they too undergo SIM, as can be seen in (19), where the irrealis pronoun $k a=$ '1SG.IR' precedes the lenited form of the prospective marker $f o$, and the initial $/ \mathrm{p} /$ of the verb pam 'to eat' is not lenited. In (20), the auxiliary pei 'be first: $R$ ' is lenited as fei and the main verb pam 'to eat: $R$ ' has no lenited initial $/ \mathrm{p} /$.

(19) Malnen kin $i=n r i k \quad$ ntwam nen kin ntwam nen $i=$ na, "A me as REL 3SG.R=tell devil that REL devil that 3SG.R=say ah but kineu $a=$ na $\quad \mathbf{k a}=\mathbf{f o} \quad$ pam akam kia me akam ra=sef." 1SG 1SG.R=want 1SG.IR=PSP.IR eat.R 2PL DEM but 2PL 2DU.R=escape 'When he said this to the devil, the devil said, "Ah but I wanted to eat you, but you ran away."”

(019:025 NT1-004-A 216.06, 217.68)

(20) I=piatlak nfag nam̃ol-in. I=na, "O me ag ku=fag, ag 3SG.R=have.R sore body-3SG.DP 3SG.R=say oh but 2SG 2SG.R=be.scabby 2SG $\tilde{\mathrm{p}} \mathrm{a}=$ fo pi temlaap $\mathrm{ka}=\mathbf{f e i} \quad$ pam tenen kina $=\mathrm{lek}-\mathrm{a}-\varnothing$ 2SG.IR PSP.IR be.R last1SG.IR=be.first.IR eat.R that REL 1SG.R=look-TS-3SG.O na nasok-on $\mathrm{i}=$ malmãal wi." DET skin-3SG.DP 3SG.R=clean good

'She had sores all over her body. He [the demon] said, "Oh but you have sores, you will be the last, I will first eat the ones whose skin I see is clean."”

(094:005 NT1-98017-B 2470.35, 2482.23)

6. MOOD AND TRANSITIVITY. The transitivity status of verbs in South Efate is rather complicated, but can be summarized as follows (for more detail see chapters 7 and 8 in Thieberger 2006a). There are several classes of verbs that can act in transitive clauses, but each behaves in slightly different ways. There are eleven transitive verbs and two ditransitive verbs and, as none of them participates in SIM they are not discussed further here. Active intransitive verbs can derive transitive verbs with the transitivizing suffix $-k i$, as seen in (21). 
(21) Me nmatu nen $\mathrm{i}=$ to $\quad \mathrm{i}=$ to $\quad$ me ki=pe mtak-ki but woman that $3 \mathrm{SG} . \mathrm{RS}=$ stay $3 \mathrm{SG} . \mathrm{RS}=$ stay and $3 \mathrm{SG} . \mathrm{PS}=\mathrm{PF}$ fear-TR maarik ntwam ne. mister devil this

'But the woman stayed and stayed and she was scared of this devil.'

(094:006, NT1-98017-B 2482.23, 2492.63)

Ambitransitive verbs can occur as underived stems in transitive constructions as in (22), and can also take a transitive suffix and $\mathrm{O}$ suffix when occurring in transitive constructions, as seen in (23).

(22) $\mathrm{Ru}=$ trau mai. $\mathrm{Ru}=$ mai plak sernale ni nafkal ola me nana. 3PL.R=just come 3PL.R=come with everything of battle spear and thingummy 'They came with all the weapons, spears and so on.'

(056:012 NT1-98002-B 920.86, 931.37)

(23) Me mama go ati kin ra=plak-e-r ru=to. but mother and grandmother REL 3DU.R=accompany.R-TS-3PL.O 3PL.R=stay 'The mother and grandmother stayed with them.'

(096:003, 98009-B 1187.76, 1193.18)

The distribution of SIM based on realis/irrealis mood has accounted for the examples presented so far, but now consider (24), where the realis form pam 'to eat:R' occurs first following a realis pronoun, as predicted, but then, later in the sentence, we find the lenited form fam 'to eat:IR' following a perfect subject, $k i=$ ' $3 \mathrm{SG} . \mathrm{PF}$ '. There is no object present, and the eating event can be interpreted as being low in transitivity using Hopper and Thompson's (1980) criteria; that is, it is ongoing or atelic. By those criteria, the perfect would seem to be correlated with higher transitivity, but clearly not where the activity is generic and lacks a specific object as is shown here.

(24) Malnen ntwam i=pam nua nait i=skei apu $i=$ slat-lu as devil 3SG.R=eat fruit fig.tree 3SG.R=one grandfather 3SG:R=take-fully nafil $\mathrm{i}=$ skei eñrom naal ga kai=pam-i- $\varnothing$. Me apu navele $3 \mathrm{SG} . \mathrm{R}=$ one inside basket $3 \mathrm{SG} . \mathrm{POS}$ ESBJ=eat-TS-3SG.O and grandfather $\mathrm{ki}=$ nrus $\quad$ fam pelpel. 3SG.PRF=move eat.IR quickly

'As the devil ate the fig, grandfather took out the navele nut (Barringtonia edulis) from his basket and ate it. And grandfather ate quickly.'

(NT1-004-A 364.72, 391.92)

In (25), the verb fam 'to eat.IR' is in the lenited form following a realis subject; again, this is not the predicted context for an irrealis stem, but note that there is no explicit object here. Later in the same sentence, the realis form follows exactly the same pronoun where it occurs with an explicit object, tete nafnag 'some food'.

(25) $\mathrm{Ra}=\mathbf{f a m}$ su tefla $=\mathrm{n}$, ra=pam tete nafnag ne, 3DU.R=eat.IR CPL thus=DST 3DU.R=eat.R some food this $\mathrm{ra}=$ slat-i- $\varnothing \quad$ pa. 3DU.R=take-TS-3SG.O thither

'They finished eating, they ate some of this food, they took it and went.' 
In (26a) and (27a), the verb has the fortis initial, the pronominal subject is not in the irrealis (which would be the precondition for an irrealis SIM form to obligatorily occur), and the action is complete as indicated by su 'CPL', which can be translated as 'completely'. This would seem to be a perfectly good context for the realis form to occur in, but it is not permitted unless an object is expressed, as shown in (26c) (where the object is encoded by a pronominal sufix) and (26d) (where the object is a lexical noun, magko 'mango').

(26) a. *Kai=pe pam su. 1SG.PRF=PRF eat.R CPL

b. Kai=pe fam su. 1SG.PRF=PRF eat.IR CPL 'I finished eating.'

(elicited)

c. Kai=pe pam-ir su. 1SG.PRF=PRF eat.R-3PL.O CPL 'I finished eating them.'

d. Kai=pe pam magko. 1SG.PRF=PRF eat.R mango 'I finished eating mango.'

(elicited) (elicited)

(27) a. $\begin{array}{r}* A=\text { pam } \\ 1 \text { SG.R }=\text { eat.R }\end{array} \quad$ CPL

$\begin{array}{ll}\text { b. } A=\text { fam } & \text { su. } \\ \text { 1SG.R=eat.IR } & \text { CPL } \\ \text { 'I finish eating.' }\end{array}$

(elicited)

Similarly, it is not possible for a fortis subject proclitic and fortis initial verb stem to be used without an expressed object, as in (27a), but the use of the irrealis in (27b) is acceptable and encodes potential future action. Examples (25)-(27) were tested with the verbs preg 'to make.R', pag 'to climb.R', and pes 'to start.R', all with the same result. Incidentally, the nature of the object in (28), a nonspecific interrogative form nafte 'what', suggests that there is no distinction made in South Efate between objects of high or low individuation or specificity, as may have been expected following Hopper and Thompson (1980). Similarly, in example (25) above, we see an object (tete nafnag 'some food') that is low in features of individuation, but that nevertheless follows the realis form of the verb pam 'to eat'.

(28) a. *Ag ku=fam nafte?

2SG 2SG.R=eat.IR what

'What are you eating?'

(elicited)

b. Ag ku=pam nafte?

2SG 2SG.R=eat.R what

'What have you eaten?', 'What have you been eating?', 'What are you eating?'

(elicited)

(29) Ag $\tilde{\text { pa }}=$ fam nafte?

2SG 2SG.IR=eat.IR what

'What do you want to eat?'

(elicited) 
(30) Ag ku=pam ntal mees pulp̃og. 2SG 2SG.R=eat taro today morning 'You ate taro this morning.'

(elicited)

In (31), the fortis form of pam 'to eat' is used with an overt object. Similarly, in (32), the fortis form of the verb pag 'to climb' is used with an overt object (nfalfat 'cave'). In both cases, the use of the progressive could be seen as reducing the transitivity of the clause, but that is clearly outweighed here by the presence of the object.

(31) $\mathrm{I}=\mathrm{na}, \quad$ "I=ku kin komam $\mathrm{u}=$ to $\quad$ pam nafnag mlanr?" 3SG.R=say 3SG.R=why REL 1EXCL.PL 1.EXCL.PL.R=PROG eat.R food cold 'He said, "Why do we eat cold food?".' (NT1-98017-B 2555.2, 2566.8)

(32) Me Litrapog $i=$ pato $i=$ to pag na nfalfat. and Litrapog 3SG.R=be.at 3SG.R=PROG climb.R DET cave 'Litrapog was there and was climbing up the cave.'

(107:011, NT1-20001-B 1059.7 1068.4)

Compare (32) with (33), in which the lenis form fag 'climb.IR' occurs with no object and with the progressive to 'PROG'; again, it is the absence of the object that allows the lenis form to occur here.

(33) $\mathrm{Ke}=$ fo si panpan nkap ke=fo pakor kaaru. Kaaru 3SG.IR=PSP.IR blow until fire 3SG.IR=PSP.IR appear other other $\mathrm{i}=$ mat me kaaru $\mathrm{i}=$ to fag. Go $\mathrm{ra}=$ to panpan 3SG.R=die but other 3SG.R=PROG climb.IR and 1EXCL.DU.R=stay until tuk mees ne. until today this

'He would blow until the fire came out of the other hole. The fire in one of the holes died but the other one was growing. And they are like this right up until today.'

(NT1-20001-B 927.8, 936.2)

Intransitive verbs cannot make the distinction that is illustrated for ambitransitive verbs above. as intransitive verbs cannot, by definition, derive a transitive form with the transitive suffix, and thus the event is, by its nature, low in transitivity. Thus in (34), falus 'to paddle.IR' is the appropriate form of the verb to occur following the irrealis subject proclitic, but later in the same sentence, the fortis form of the stem, palus 'paddle.R' encodes an event (paddling) for which, were palus an ambitransitive verb, we would have expected a lenited form to occur.

(34) Selwan ru=totan na ruk=falus go ru=totoluk-ki nakpei while 3PL.R=sit PURP 3PL.IR=paddle.IR and 3PL.R=turn.back-TR front nig raru po palus.

of canoe PSP paddle

'While they sit in order to paddle they turn their backs to the front of the boat then paddle.'

(026:022)

In example (35) from the 1871 Bible translation of John, we see the realis form of the verb pam 'to eat.R' used where there is an overt object. In the 1885 translation (36), we find the irrealis form of the same verb following a realis subject pronoun because there is 
no overt object. The phrase nafamien kotfan 'afternoon feast' does not act as an object here, as it occurs after the completive particle $s u$.

(35) $A k a m ~ k u=f$ tu pam nafsik Nan natamol mou. ${ }^{6}$ 2PL 2SG.R=CND NEG eat flesh child person NEG2

'Except ye eat the flesh of the Son of man.'(Nafsana wi ... 1871; Ioane 6:53)

(36) $\mathrm{Ru}$ fam su nafamien kotfan ... 3SG.R eat.IR CPL feast afternoon

'And supper being ended ...'(The Gospel according to John 1885, 13:1)

Macdonald (1889:10), writing at the end of the nineteenth century, noted the presence of stem-initial mutation: "b and fare changed constantly, and often the one or the other is used according to the caprice of the speaker, or as to his idea of euphony." It is clear from the preceding discussion that the use of realis and irrealis forms conforms to a predictable rule and is neither the result of caprice, nor of euphony. These examples show that SIM has been associated with more than just mood marking for as long as we have records of the language.

In summary, as shown in (37), a fortis form of the subject can cooccur with the fortis form of the verb when there is an overt object, but takes the lenis form of the verb when there is no overt object and the activity is thus interpreted as being generic or progressive.

(37) Realis Subject - fortis form of $\mathrm{V}$ with overt $\mathrm{O}$

Realis Subject - lenis form of V without overt O (readings include

Irrealis Subject - lenis form of verb generic, progressive activity)

The correlation of mood and transitivity is not unexpected following Hopper and Thompson's (1980) observation that transitivity correlates with mood distinctions and individuation of the object, among other features.

7. FREQUENCY OF SIM FORMS. SIM marks a mood distinction in only 60 South Efate stems. Further, realis marking is used to encode the higher transitivity associated with the presence of an overt object. But how has this distinction continued to be encoded in such a small set of verbs, apparently for at least 140 years?

A possible explanation for the retention of SIM lies in the high functional load of words and particles that undergo SIM. It is known that irregularity in language in general is correlated with high frequency forms (for example, Bybee 1995, Haspelmath 2006), so it is worth looking at the frequency of the SIM forms in a corpus of South Efate texts. ${ }^{7}$ Table 5 lists the frequency of word tokens ${ }^{8}$ with more than 100 occurrences, and shows that the prospective marker po/fo occurs 204 times as the irrealis $f o$ and 106 times as the

6. This example is given as in the original. The number mismatch her-akam 2PL vs. $k u=$ $2 \mathrm{SG} . \mathrm{R}$ - is taken as being a mistake in that translation. Similarly, the lack of tilde in natamol 'person' is a feature of the earlier translation.

7. Frequencies were calculated by counting word forms (space-delimited forms) in the morphemic line of a set of 71 interlinear glossed texts with a total of some 19,500 words.

8. MacWhinney (2001:464) discusses the importance of counting tokens as they "have their effect through repeated activation of the same type nodes." Corbett et al. (2001) note that high token frequency correlates with irregularities and that pure token frequency rather than paradigmatic relations allows irregularity to be maintained. 
realis $p o$. The verb $p a$ 'to go.R' is also very common, with 133 occurrences, while its irrealis form $f a$ 'to go.IR' occurs only five times. It is significant that eight of the 35 most frequent words in the corpus are SIM-eligible. Table 1 (above) lists the frequency of all SIM-eligible forms in the dataset, showing that they are not marginal in their distribution.

TABLE 5. FREQUENCY OF OCCURRENCE OF WORD TOKENS $(\geq 100)$

\begin{tabular}{|c|c|c|c|c|c|}
\hline WORD & FREQUENCY & $\begin{array}{l}\text { ELIGIBLE } \\
\text { FOR SIM }\end{array}$ & WORD & FREQUENCY & $\begin{array}{l}\text { ELIGIBLE } \\
\text { FOR SIM }\end{array}$ \\
\hline $\mathrm{i}=$ '3SG.R' & 2,108 & & preg 'make' & 153 & YES \\
\hline ki '3SG.IR/PREP' & 572 & & ku ‘2SG.R' & 150 & \\
\hline me 'and, but' & 566 & & ke '3SG.IR' & 146 & \\
\hline go 'and' & 534 & & panpan 'until' & 145 & \\
\hline na 'DET' & 533 & & skei 'one' & 135 & \\
\hline ru '3PL.R' & 519 & & pa 'go.R' & 133 & YES \\
\hline to 'stay, PROG' & 506 & & tu 'at' & 130 & \\
\hline kin 'REL' & 379 & & piatlak 'have.R' & 123 & YES \\
\hline nen 'REL' & 362 & & ka '1SG.IR' & 120 & \\
\hline mai 'come' & 276 & & e 'LOC' & 116 & \\
\hline a '1SG.R' & 266 & & lek 'look' & 114 & \\
\hline pan 'go:DST' & 263 & YES & p̃a '2SG.IR' & 111 & \\
\hline pi 'be' & 226 & YES & tete 'some' & 109 & \\
\hline pak 'go to' & 223 & YES & po 'PSP.R' & 106 & YES \\
\hline ni 'of' & 210 & & tae 'know' & 104 & \\
\hline fo 'PSP.IR' & 204 & YES & pe 'PERF' & 103 & \\
\hline ga '3SG' & 199 & & nrik 'say' & 100 & \\
\hline ra 'DU.SBJ' & 195 & & & & \\
\hline
\end{tabular}

TABLE 6. TOKEN FREQUENCY OF WORD TYPES

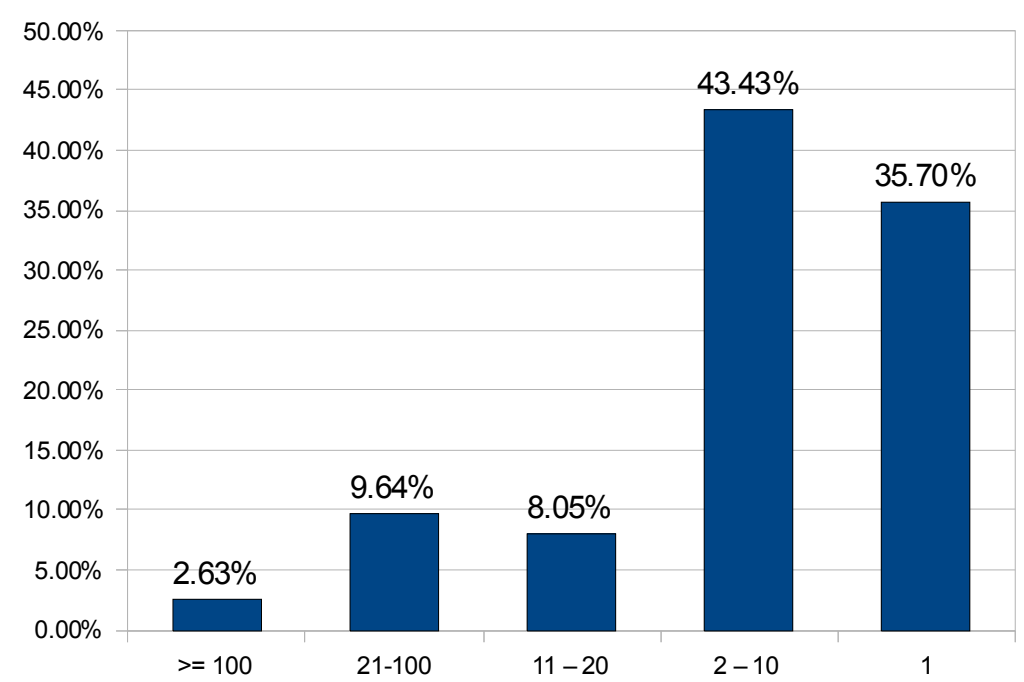

Number of tokens 
Table 6 should be read as follows. Words that occur once account for 35.7 percent of tokens, words that occur over 100 times account for just 2.63 percent of tokens, and, as we saw in table 4, eight of these forms are eligible for SIM. These figures indicate that SIM-eligible forms are indeed very well represented in the corpus, and this, I suggest, could provide an explanation for the continuing use both of SIM itself and of the use of SIM in marking degrees of transitivity.

In conclusion, we have seen that SIM is a marginal process in South Efate, applying to only 60 of some 870 verbs. The main function marked by mutation is mood, but with an additional function of encoding intransitivity. The high frequency of SIM forms in discourse is suggested as an explanation for the ongoing use of what would otherwise appear to be a marginal morphological system.

\section{REFERENCES}

Bybee, Joan. 1995. Regular morphology and the lexicon. Language and Cognitive Processes 10(5):425-55

Comrie, Bernard. 1976. Aspect: An introduction to the study of verbal aspect and related problems. Cambridge: Cambridge University Press.

Corbett, Greville, Andrew Hippisley, Dunston Brown, and Paul Marriott. 2001. Frequency, regularity and the paradigm: A perspective from Russian on a complex relation. In Frequency and the emergence of linguistic structure, ed. by Joan Bybee and Paul Hopper, 201-26. Amsterdam: John Benjamins.

Crowley, Terry. 1982. The Paamese language of Vanuatu. Canberra: Pacific Linguistics. . 1991. Parallel development and shared innovation: Some developments in Central Vanuatu inflectional morphology. Oceanic Linguistics 30:179-222.

. 1998. An Erromangan (Sye) Grammar. Honolulu: University of Hawai'i Press 1999. Ura: A disappearing language of Southern Vanuatu. Canberra: Pacific Linguistics.

Dahl, Östen. 1985. Tense and aspect systems. Oxford/New York: B. Blackwell.

François, Alexandre. 2009. Verbal aspect and personal pronouns. In Austronesian historical linguistics and culture history: A festschrift for Robert Blust, ed. by Alexander Adelaar and Andrew Pawley, 179-95. Canberra: Pacific Linguistics.

Haspelmath, Martin. 2006. Frequency vs. iconicity in the explanation of grammatical asymmetries. MS.

Hopper, Paul. J., and Sandy A. Thompson. 1980. Transitivity in grammar and discourse. Language 56(2):251-99.

Lynch, John. 1975. Oral/nasal alternation and the realis/irrealis distinction in Oceanic languages. Oceanic Linguistics 14:87-99.

. 2001. The linguistic history of Southern Vanuatu. Canberra: Pacific Linguistics.

Macdonald, Donald D. 1889. Three New Hebrides languages (Efatese, Eromangan, Santo). Melbourne: Edgerton and Moore.

MacWhinney, Brian. 2001. Emergentist approaches to language. In Frequency and the emergence of linguistic structure, ed. by Joan Bybee and Paul Hopper, 449-70. Amsterdam: John Benjamins.

Nafsana wi nig Yesu Krist nag Yoan ki mtir i. [New Testament].1871. Auckland: "Daily Southern Cross" Office [trans. by Rev. James Cosh]. 
Pawley, Andrew. 1969. On the internal relationships of Eastern Oceanic languages. Paper presented at the Wenner-Gren symposium on Oceanic culture history, Sigatoka, Fiji.

Schütz, Albert J. 1968. A pattern of morphophonemic alternation in Nguna, New Hebrides. In Papers in the Linguistics of Melanesia 1, ed. by A. Capell et al., 41-52. Canberra: Pacific Linguistics.

. 1969. Nguna grammar. Oceanic Linguistics Special Publication No. 5. Honolulu: University of Hawai'i Press.

The Gospel according to John. Tus Nanrognrogona Uia ni Iesu Kristo nag Ioane $i$ mitiria. 1885. Sydney: F. Cunninghame and Co. [trans. by J. Mackenzie and D. D. Macdonald]

Thieberger, Nicholas. 2006a. A grammar of South Efate: An Oceanic language of Vanuatu. Oceanic Linguistics Special Publication No. 33. Honolulu: University of Hawai'i Press.

. 2006b. The benefactive construction in South Efate. Oceanic Linguistics 45: 297-310.

2007. The demise of serial verbs in South Efate. In (eds.), Language description, history and development: Linguistic indulgence in memory of Terry Crowley, ed. by Diana Eades, John Lynch, and Jeff Siegel, 237-51. Amsterdam: Benjamins.

Tryon, Darrell T. 1986. Consonant alternation on Epi. In FOCAL II: Papers from the fourth international conference on Austronesian linguistics, ed. by Paul Geraghty, Lois Carrington, and S. A. Wurm, 239-58. Canberra: Pacific Linguistics. 